
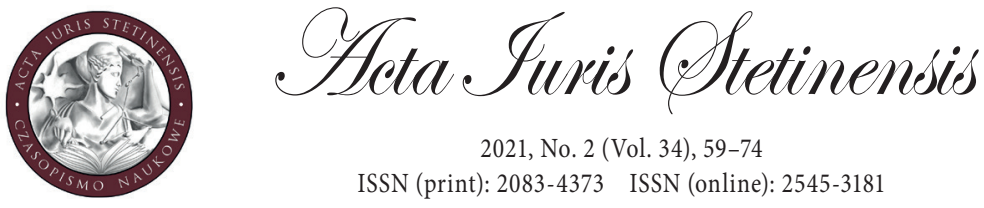

2021, No. 2 (Vol. 34), 59-74

ISSN (print): 2083-4373 ISSN (online): 2545-3181

DOI: $10.18276 /$ ais.2021.34-04

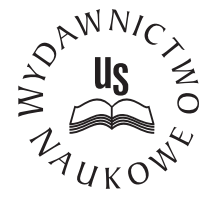

Judit Tóth

Associate Professor

OPEN ACCESS

University of Szeged, Hungary

e-mail: alkotmanyjog@juris.u-szeged.hu

(c) (i) (2)

ORCID: 0000-0001-5236-0436

Renáta Kálmán

Assistant Professor

University of Szeged, Hungary

e-mail: kalman.renata@juris.u-szeged.hu

ORCID: 0000-0003-0459-8233

\title{
Legal education at the crossroads of social responsibility and the development of individual competencies - experience at the University of Szeged (Hungary) ${ }^{1}$
}

\begin{abstract}
The authors describe the role of the legal clinical education as an instrument for community empowerment through pro bono legal counseling, easily understandable e-compilation (Vademecum) of legal terms, and extended legal practice for law students, together with the development of their professional competencies. The new requirements in legal education, as determined by the government in 2016, focus on labour market needs, but academics and leaders of the University of Szeged have created an amalgam of tools for access to justice for local residents and NGOs in a less wealthy social environment, thereby introducing changes
\end{abstract}

1 The research for this study was carried out with the support of the programs of the Hungarian Ministry of Justice enhancing the standards of legal education. 
in education. The article proves how difficult it is to change historically-determined traditions in legal education in an innovative way, developing social solidarity, legal responsibility, ethics, and communication skills of the future generation of jurists in Hungary. In the course of the research, the authors analyze their own experiences since the establishment of the Legal Clinic at the University of Szeged under predefined requirement, e.g. number and type of cases or form of help. As a result, key fields are revealed where the work of the Legal Clinic is essential, and such a conclusion provided great help to further develop the partnership system and the entire clinical legal education at the University of Szeged.

Keywords: professional competencies of jurists, legal education, legal clinics, Hungary, social responsibility of the university

\section{Introduction}

In Hungary, the beginning of university legal training dates back to 1667 , which means centuries in the tradition of high-level theoretical education, with special attention to the needs of the state (education of officials, judges, prosecutors, and public notaries). Then, legal academies focusing on practice appeared with the help of the Reformed and Protestant Churches that were flourishing in the 19th century. The training tradition includes text-bound interpretation of the law, a high degree of formalism, as well as historical and analytical approaches in law. The Hungarian training system follows the continental model, in which the role of the state is decisive in terms of requirements, financing, and appointments at universities, as the state agencies and organizations build on graduate lawyers. ${ }^{2}$

Legal education has traditionally meant five years (10 semesters) of uniform/ long-cycle period of study. Even though the Bologna system prescribed two cycles of education for BA and MA degrees in 2006, this approach has been formally refused. On 17 May 2003, at the Deans' meeting, the resistance was worded as follows: "the two-cycle structure is alien to the function and peculiarity of legal education." Therefore, specialized legal training (LLM for a legal subdivision) is only possible after obtaining a uniform university degree. There is a doctoral school in all law faculties, where a scientific degree $(\mathrm{PhD})$ can be obtained. Each legal training and doctoral school requires the approval through a state accreditation procedure.

2 Zs. Nagy, A jogi oktatás fejlődése és aktuális kérdései, Szeged 2007, pp. 68-69. 
Nowadays, legal education is provided at two universities established by churches and six state-funded universities. These are complemented by two private universities, where LLM legal training is available in some topics (Central European University and the Andrássy University). However, as of 2020, nine of the state-founded universities, including two faculties of legal education, have become privatized universities: the state has delegated the rights of its maintainers and, optionally, its founders to a board of trustees consisting of private individuals. The members of the board of trustees were appointed by the government, so the state handed over the real estate needed to operate the university and the responsibility for running it to a few people of its choice. A university thus privatized may enter into a public service contract with the government to fund a certain number of students if the university meets the requirements for accreditation. But in the future, students' tuition, scholarships, and talent management will be the responsibility and task of the privatized university. ${ }^{3}$ Moreover, the National University of Public Services, which is a government-established and - sustained university, issues a public administration diploma, but at any moment this university can start offering legal education giving additional supply for government agencies and departments. However, this privatization differs from Tilak's typology (extreme, strong, moderate/gentle and pseudo-privatization $)^{4}$ because some institutions involved in privatization were consulted, some received special state-owned assets, and others did not receive adequate guarantees, even despite teacher and student strikes. It has a privileged status and enjoys significant budget support among staterun universities. Yet there is one common element of privatization: the decline in the autonomy of higher education institutions ${ }^{5}$, which is not only a theoretical threat but a reality.

3 The basic educational activities of a higher education institution include higher education vocational training, undergraduate training, master's training, doctoral training and specialized further training. Unless otherwise provided by this Act, only higher education institutions may carry out activities falling within the scope of basic educational activities. Maintaining this principle, from 2021 onward the CEU will no longer pursue legal LLM training in Hungary, and in two law faculties the state has transferred its founding rights to the board of trustees of the foundation that operates the university (including the law faculties in Györ and Miskolc). This is regulated by recent amendments (Act XIX of 2019, Magyar Közlöny (Official Journal) 2019/50:1678, Act XXXVI of 2019, Magyar Közlöny (Official Journal) 2019/63:2099, and Act XXXIII of 2020 Magyar Közlöny (Official Journal) 2020/125:2978) to Act CCIV of 2011 on tertiary education, Article 73/A and 104, Magyar Közlöny (Official Journal) 2011/165:41181.

4 J.B.C. Tilak, La privatisation de lenseignement supérieur, "Perspectives" 1991, No. 2, pp. 251-265.

5 A. Németné Doktor, A magyarországi magán-felsőoktatás, “Új Pedagógiai Szemle” 2008, No. 8-9, p. 58. 
With this, essentially three types of university models were created in legaladministrative training in Hungary by 2020: traditional state-funded and state (budget-supported) university training; privatized but originally state-funded university education; and university education founded by a non-state entity (church, private persons, etc.). In such a small country, this diversity was neither the result of organic development, nor of long-term knowledge management. Rather, these three types of models can be explained by the operation of different economic and political/ideological lobbies. Churches and economic power groups interested in privatization gradually obtained resources drawn from traditionally operating public universities, regardless of the quality of training and university rankings. In this environment, legal training must take place at the University of Szeged that is statemaintained (up until August 20216) and state-founded.

By the year of 2000, the number of law students reached a peak (about 18,000), since after the collapse of socialism in 1989, the market economy and the establishment of the rule of law, compared to previous decades, required many more lawyers. After 2010, the government has tightened the requirements for admission to legal education and raised student fees, while public finance has been kept to a minimum for legal education, with the exception of grants to church universities. This has led to a greater drop in the number of students (and social mobility) than demographic changes, so that more or less, children in the middle or upper social classes can choose legal education. In 2012, law students in Hungary accounted for four to five percent of the total number of students, which is low in international comparison, whereas the EU average is twice of that. At the same time, the proportion of students working during their legal training is increasing, at least by $60 \%$. Approximately $15 \%$ of law students also take one or two semesters at other universities abroad, tasting some cultural and legal diversity. Despite these changes, only $34 \%$ of recently graduated lawyers joined private companies (2015), and two-thirds of them accessed employment in the public sector. ${ }^{7}$

In the light of these general characteristics, we need to compare two things: what are the requirements (determined by the state) for legal education in terms of outputs, and how can these be fulfilled by the University of Szeged, by developing

6 After the submission of the manuscript, under pressure from the government, 21 state-maintained universities were transformed into private universities, including the University of Szeged (Act VIII of 2021 and Act XXIII of 2021, Magyar Közlöny (Official Journal) 2021/75: 2753-2862).

7 Zs. Körtvélyesi, A magyar jogászképzés 2015-ben - A jogi karok helyzete, in: A. Jakab, G. Gajduschek (eds.), A magyar jogrendszer állapota, Budapest 2016, p. 921. 
the knowledge and competencies of the students and through their familiarization with legal practice.

\section{New Output Requirements for legal education}

In 2019, the Minister of Education defined uniformly general output requirements for students in tertiary education as follows: acquisition of professional competencies, including digital competence corresponding to vocational/professional training, digital skills, media awareness, safe use of the Internet, effective use of digital technology, knowledge of digital solutions to achieve learning goals, and basic knowledge of health promotion and sustainable development, including basic knowledge of environmental, accident, work, and consumer protection. These general expectations mean the foundation upon which the Master's program is built. An MA degree may only be obtained by a person who has the appropriate (a) professional (cognitive) knowledge, (b) ability/proficiency, (c) professional attitude, and (d) autonomy and competence relevant to responsibility. These four major components form the students' output requirements, which are based on a conceptual basis known in adult education. ${ }^{9}$

The third level of outputs are the criteria of legal education ${ }^{10}$ : at least 300 credits must be obtained in long-cycle training, $70-80 \%$ of which comes from theoretical performance; at least 30 credits for the final thesis, and 15 credits for elected/ optional part of the curricula shall be obtained. Therefore, legal education belongs to the higher education sector with a high theoretical need, although, there is an ongoing debate in the legal training on a greater proportion of practical knowledge, and consensus has emerged against radical changes. "If we break the system of legal science education and take it strongly towards practical training, then the education itself and the legal-dogmatic as a foundation will be jeopardized." ${ }^{11}$

8 Ministerial Decree of Human Resources No. 3 of 11 February 2019 on tertiary professional education's output competences, Article 8, Magyar Közlöny (Official Journal) 2019/19:25.

9 É. Farkas, The practice of adult education and vocational training in Hungary, Szeged 2013, pp. 50-51.

10 Ministerial Decree of Human Resources No. 18 of 5 August 2016 on training and output requirements for vocational training in higher education, basic and master training, and output requirements for individual teaching periods, Articles 8-10 with Appendix, Magyar Közlöny (Official Journal) 2016/116:10408.

11 B. Pokol, Presentation of the conference on current problems in legal education in Hungary, https://www.ajk.elte.hu/file/25_PokolBela-JogaszkepzesDilemmai.pdf (accessed 20.05.2019). 
At the same time, based on a survey, ${ }^{12}$ aw students complain that there are too many compulsory subjects, there is a limited possibility to create a personalized timetable, and if someone takes up extra hours of interest, it will result in financial consequences after reaching the maximum of 330 credits. On the other hand, practical knowledge can only be acquired after graduation, during the minimum of three years in the attorney-at-law, judge, prosecutor or notary training, which serves as a precondition of taking a professional bar exam. However, passing such a legal exam requires at least another year. Therefore, a minimum of nine years of full-time training is required for the license of a legal profession in Hungary, but during this long period, the individual learning and professional personal motivation is gradually weakened. However, with the transformation of legal training, equal opportunities and social mobility has been reduced from 2012 onwards, young people from poorer families have no chance of entering university education, and this has deprived legal training of one of its essential social functions. Thus, in a broader public policy environment, legal education does not reduce but reinforces the reproduction of social inequalities. According to another survey, ${ }^{13}$ conducted by law students, the most important qualities of law practitioners include honesty, sense of justice, good verbalism, logical thinking, and empathy (they are ranked as the most prominent ones).

The Ministers responsible for legal training did not take a stand in this debate but prioritized talent management and the reduction of disadvantages of legal universities outside the capital. It has provided additional resources for grant and scholarship funds totalling EUR 1,562,500 (2015-2019), ${ }^{14}$ as the income of rural families is lower compared to the highly supported Church Universities and National Public Service University applicants in the capital, thus they are less able to finance their children's legal studies. However, this symbolic compensation does not imply the withdrawal or reversal of austerity measures of the contemporary education policy that seriously affects education in social/legal sciences.

12 V. Visnyei, A jogászképzés és a jogászi professziók Magyarországon, “Comparative Law Working Papers" 2018, No. 1, Special Issue by Students, p. 62.

13 H. Feith, A. Badó, Magyar joghallgatók motivációs vizsgálata, "Jogelméleti Szemle” 2000, No. 4, p. 16.

14 Government Resolution No. 1311 of 21 May 2015 on providing resources for legal research and talent management concerning some important public policy goals, Articles 1-3, Magyar Közlöny (Official Journal) 2015/69:6268. 


\section{The social context in Szeged}

The University of Szeged traces its origins back to 1581 with the foundation of the Academia in Cluj (Kolozsvár). István Báthory, Prince of Transylvania, King of Poland (1571-1586) and Grand Duke of Lithuania took measures to establish a Catholic university consisting of two faculties, Arts and Theology. The modern university operation with 12 faculties ${ }^{15}$ dates back to 1921 in this city, including the comprehensive research of our Nobel Prize-awarded professor ${ }^{16}$ and the establishment of the ELI Laser Research Centre ${ }^{17}$ in 2014.

The Faculty of Law and Political Sciences has numerous branches beyond the traditional legal education, including studies on international relations, legal assistance, mediation, labour relations, social insurance, legal translator LLM in English and German, LLM of Business Law and LLM of Family Law. This complex portfolio means that there is a significant interdisciplinary approach among students and teachers, there is some interoperability between disciplines, courses, and thus students may see a much broader horizon instead of narrow legal norms. Complexity is also a characteristic of Hungarian and English-language doctoral programs; therefore, the number of foreigners entering into doctoral programs is increasing.

Overall, according to research conducted in 2017, almost two-thirds of Szeged law students have a parent with a degree. ${ }^{18}$ On the other hand, the children of families with lower educational attainment and who live in smaller settlements also have the chance to receive a higher education diploma. One explanation for this is the student loan system and the scholarships and grants provided by the university. In this social environment, the legal education in Szeged has made efforts and reached success that can be described and developed in three directions:

15 Faculties: Arts, Agriculture, Humanities \& Social Sciences, Dentistry, Economics \& Business Administration, Engineering, Health Sciences \& Social Studies, Law \& Political Sciences, Medicine, Pharmacy, Science \& Computer Science, Education.

16 Albert Szent-Györgyi was awarded the Nobel Prize in 1937.

17 The Extreme Light Infrastructure Attosecond Light Pulse Source (ELI-ALPS) Laser Research Centre is one of the pillars of this infrastructure. It was built in Szeged and is one of the largest scientific investments in Europe. It received support from the European Union amounting to over HUF 70 billion. This allows researchers to examine elementary intra-molecular physical processes and also provides unparalleled infrastructure to carry out basic and applied research on an ultrafast timescale for outstanding research results in biology, medicine and material sciences. Its purpose is to establish a unique, laser-based European user research facility where ultra-short laser pulses and light sources have been accessible for international researchers since 2019.

18 A. Badó et al., Összehasonlító motivációs vizsgálat a szegedi joghallgatók körében, "MTA Law Working Papers" 2017, No. 11, pp. 12-13. 
(a) developing students' competences, (b) offering insight into legal practice, and

(c) strengthening social responsibility. Retaining the traditions of legal education, major innovations have been introduced over the past decade, which can be summarized as follows:

- arranging and presenting litigation simulations with courtroom equipment and robes in a specially designed room;

- introduction of rhetoric courses and competitions to develop students' oral ability;

- introduction of a lawyer's dispute culture course to allow students to cultivate their legal thinking, argumentation technique, concentration, and tolerance;

- development of digital learning materials that promote self-study and part-time students' preparation for their tasks;

- introduction of legal IT education and practice; renewal and transfer of statistical training delivered in a computer room; preparation of financial/judicial statistical analyses; preparation of data series;

- human rights and fundamental rights conflicts are also dealt with in special courses with the help of world literature and film;

- easily understandable e-compilation (Vademecum) of legal terms has been drawn up. In the course of its preparation, law students, $\mathrm{PhD}$ students, and professors worked together as a team to create a database, which is easily understandable and contains normative content concerning definitions and legal institutions. This 200 -word compilation is available on the Internet ${ }^{19}$ and it intends to raise the level of legal awareness, to provide help for civil organizations, and to inform persons who need legal assistance. It is limited to terms that can be used in everyday life (e.g. court system, divorce, student card, tax exemption, etc.). At the same time, such work represents a good example of the university's social responsibility, too;

- access to legal praxis is facilitated by 6 weeks of practice (court, prosecution, police, and law firm) organized by the university for all law students, but this period can be extended by the Career Office and traineeships for committed students. Businesses and non-profit organizations offering legal work in the region hire the students as part-time staff. The selection process and contracts are reviewed by the university;

- by concluding volunteer contracts, students can be involved in the research works of certain departments and institutes;

19 http://www.u-szeged.hu/efop362-00007/koszonto/koszonto (accessed 25.09.2020). 
- the introduction of legal ethics on general issues of law and specialized courses (focusing on certain legal areas or legal professions) has happened recently, including the development of the necessary textbook, which was a serious deficiency, since it was absent in the legal education during the period of socialism and raw capitalism;

- output-based conversion of the curriculum in each discipline has already been implemented;

- the Erasmus scholarship provides an opportunity to improve the knowledge of foreign languages and legal culture of other European countries. Such scholarship is made available for at least one semester and thanks to the financial support of the university and the European Union;

- introduction of clinical legal education as an optional course for law students. According to this non-exhaustive list, it may seem that the greatest result is that at several points we have managed to break the dominance of frontal education and to reduce the passivity of students by implementing educational solutions that mobilize group dynamics and emotional and moral intelligence of law students, which is a multifaceted goal in the development of their competences.

\section{Efforts and achievements in legal clinical training}

The legal clinic (LC) as an alternative (non-frontal) form of education stands out in the sense that it requires significant commitment to the size and stability of personal, material, and financial conditions.

Since 2005, the legal clinic has operated continuously at the University of Szeged Faculty of Law and Political Sciences, involving an average of 15 students per semester (attending the 3rd-9th semester) under the supervision of 5-6 tutors (attorneys-at-law and senior teachers). This LC, which has the longest uninterrupted history in Hungary, is hosted by the Department of Constitutional Law. It means that all of its tutors work in joint positions or as part-time university staff. Unfortunately, since it is not an independent unit in the university structure, it has no specialized administrative staff. The guidelines of operation, its place inside the curricula, and the number of all 9 credits - that is marginal - were approved by the Faculty Council.

There are three main equally relevant goals of the LC:

- making experimental courses available to some students that are interested in them;

- preparing students for the legal profession; 
- giving disadvantaged groups access to legal services, providing a live client experience for students.

The LC I-II-III as optional courses are divided into three substantial parts:

- preparatory course that takes 3 days (22 hours) (legal, institutional, communication, administrative, and psychological training for students with guest speakers and tutors);

- legal counseling for any contractual partner (NGOs and segregated clients in their institutes, city hall, or NGO offices), at least 30 hours per semester, delivered by the students in situ (student duty hours for meetings with clients);

- reporting cases to the tutors and consultations with them, at least 16 hours per semester.

The total number of clients assisted through free legal aid at LC in Szeged was 718 within twelve years. Together with family members of the persons who requested legal assistance, this number amounts to at least 2,350 people. Figure 1 demonstrates the case types handled the LC: anti-discrimination law, non-profit organizations law, housing, social allowances, social insurance, municipal law, labor law, rights of persons with disabilities, family law and child protection. Penal, migration, commercial or corporate law is not part of LC's portfolio.

\section{Types of cases}

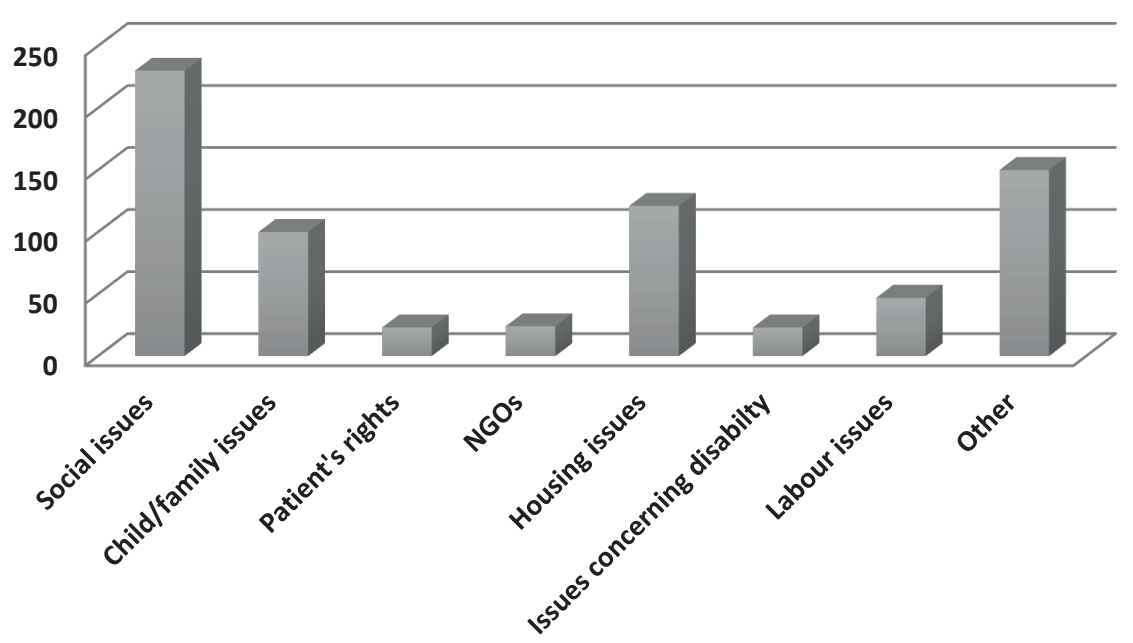

Figure 1. Types of legal cases in the LC in Szeged 
The legal counseling of LC is hardly compatible with court cases with mandatory professional representation due to the strict deadlines and absence of malpractice liability insurance. In this way, the majority of legal assistance involves explanation of legal conditions, public administration or municipal procedures, mediation in a conflict, or preparation of a law suit. Figure 2 illustrates the forms of the help provided.

\section{Forms of help}

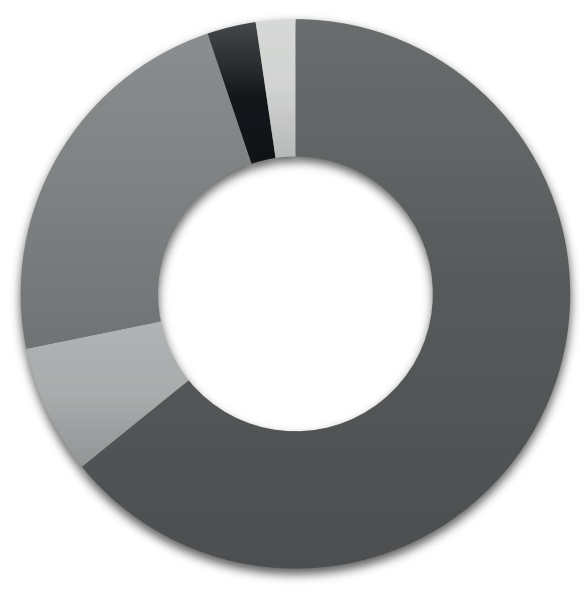

- Legal advice (471)

- Referral to competent authority (56)

Writing applications/official letters (169)

- Referral to attorney (21)

Other (17)

Figure 2. Forms of help by the LC in Szeged

Source: authors' own research

The LC has numerous partners under biannual partnership agreements with local NGOs representing victims of household violence, drug abusers, Roma people, persons with disabilities, unemployed, sick or homeless persons, large families, abandoned children in need, and recently the local/regional municipal social departments and the National Centre of Patients, Children and Residents of Care Homes that may refer persons suffering from exclusion to the LC. In this way, NGOs and local municipalities promote the LC services and manage potential clients' access during office hours at the NGOs' seat. On the other side, with independence in its profile, the responsibility of LC is guaranteed in a cooperative spirit. For instance, the LC accepts legal claims of NGOs to amend deeds of foundation 
or project planning, while in exam and summer periods, it is the tutors who have to manage urgent claims. Figure 3 demonstrates the interrelations between the LC and its partners.

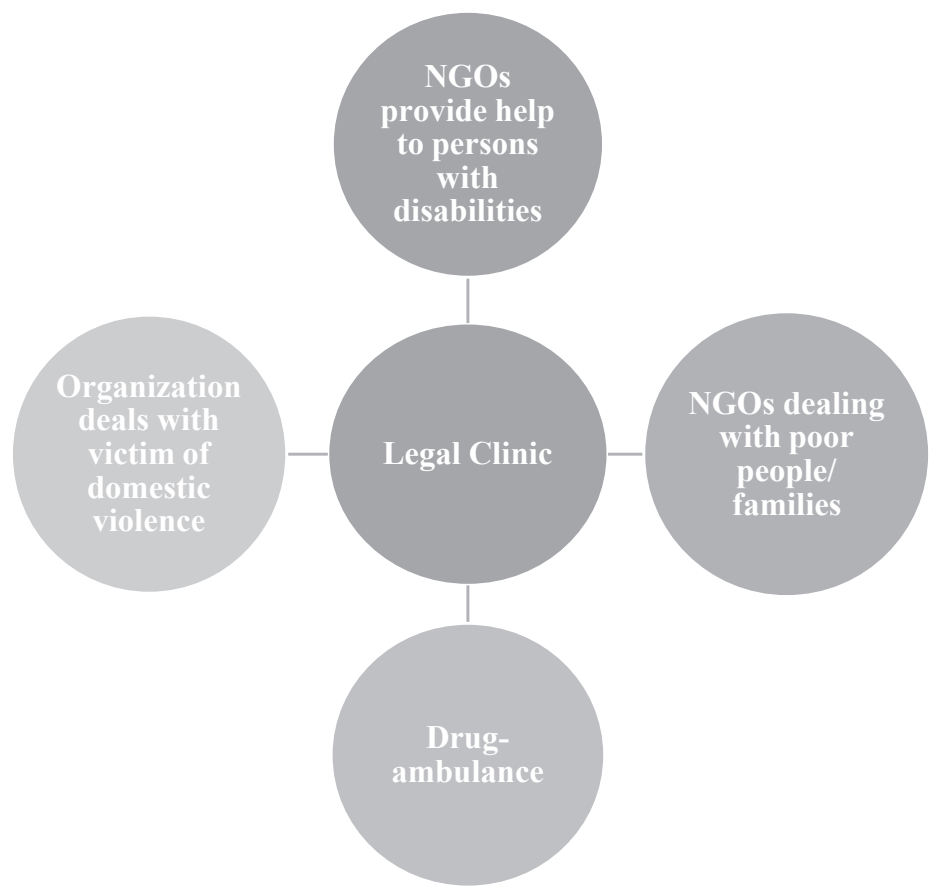

Figure 3. Interrelations between the LC and its partners

Source: authors' own research

The specific form of cooperation is the Legal Forum, where, upon a joint request of civil society organizations, the tutors of LC deliver presentations in a clear language (e.g. on personal data processing in accordance with the GDPR, protection of intellectual property, and copyright protection of content used in promotion materials by civil organizations, the legal position of volunteers and employees in the non-profit sector) and receive questions, while individual or common legal problems are answered with the involvement of law students. Questions are usually sent in advance by NGOs. It is also part of the LC activity, upon a request of a partner organization, to provide a consultation with a short introduction by a tutor (e.g. what rights shall be ensured for visually impaired persons in higher education, how banks should serve customers with disabilities, or what should be done concerning 
cyberbullying). Such requests are handled by the students who deliver short legal presentations on the topics requested (e.g. the rules of wills for elderly residents of care homes). These activities are similar in form to street law actions, but the latter are held occasionally and only upon request.

The LC infrastructure is very solid: it has its own office ${ }^{20}$ inside the university facilities for training and tutorial consultations and board meetings with representatives of the partners. The LC is advertised on the Faculty's homepage, ${ }^{21}$ where anyone could find information, for instance, on how to join study tours to local social and NGO institutions or on how the students evaluate the work of LC work (e.g. the number of credit is not proportional to the efforts of the student in clinical education and counseling). Despite the limited enthusiasm of law teachers and the awareness of clinical education, non-regular students (law students at evening courses or foreign ERASMUS students attending the course on non-profit law in Hungary) requested for the door to be opened to them. Since 2011, the LC has been available for non-regular students as well. From time to time, information on the LC in local media (radio and press) provides certain publicity for this social undertaking. As the capacity of the legal assistance service for those who need it organized by the state is limited by the free or fixed tariffs, its alternative would come in the form of a clinic for the poor or non-profit organizations operating in and around the university city. ${ }^{22}$ Although there is legal clinic education at other law faculties in Hungary, their operation is not continuous, thereby there is little curriculum and textbooks for legal clinics are only available in Budapest (ELTE $\left.{ }^{23}\right)$ and Szeged. ${ }^{24}$

\section{Conclusions}

In Hungary, the share of university education inside adult education is stagnating or decreasing, while participation in various training schemes outside the school system is increasing, mainly due to changes in training needs, public finance and

20 The only external support towards purchasing furniture and PCs for the LC office was provided by the Tertiary Education Fund in 2005-2006.

21 www.juris.u-szeged.hu/oktatas/gyakorlati-kepzesek/jogklinika (accessed 20.09.2020).

22 J. Tóth, Legal Clinic as a Promising Alternative Instrument in Hungary, "Jogelméleti Szemle" 2017, No. 4, pp. 152-153.

23 F. Tóth, A jogklinikai képzés módszertana, in: ELTE, Oktatásmódszertani Füzetek, Vol. 4., Budapest 2017.

24 J. Tóth, Kézikönyv a jogklinikai képzéshez, Szeged 2017. 
forms of employment. The state provides fewer and fewer resources for university education and especially for social science training, so those who want to study (and their families) have to finance their own learning to an increasing extent. ${ }^{25}$ This circumstance will only inspire reforms in legal training and education if market participants also invest additional resources in this sector, so that the competencies and professional abilities of those choosing the legal profession can be comprehensively developed, including the changing of attitudes of instructors and professors.

Legal education at the University of Szeged cannot change traditions quickly, the state's strong influence on university operations and customer priorities based on the needs of the public sector have a great impact on the training. The introduction of output requirements and the slow spread of non-frontal education will ensure a paradigm shift in the near future.

Clinical education in Hungary has achieved limited success because the traditions of textualization, strict interpretation of legal sources and the distance between the legal practice and theory of law is wider than the pressure for changes in the market economy and pluralistic civil society. Nowadays, legal practitioners are alienated from case law, international or ECJ case or customary law due to theoretical traditions in legal studies, yet the enthusiasm of the new generation of lawyers towards case law and professional skills are considered as misfits by the majority of professionals.

Due to internal and external conformity, frontal education remained dominant and attempts of mediation, moot courts, and legal clinics appear as exotic exceptions in uniform, non-specialized legal education. The values of autonomy, democracy, competitiveness, and professional efficiency in contemporary society are weak, ${ }^{26}$ which is why fragmented networks (of teachers, alumni, clinics, and

25 É. Farkas, Financing the adult education system in Hungary, in: B. Németh (ed.), Research and Development in Adult Learning and Education in Hungary, Bonn 2015, p. 43.

26 The value system was surveyed in 2009 and in 2013, proving minimal changes: Hungarians value secularization but feature closed, inward, and paternalistic attitudes; the level of public trust and individual confidence is the lowest in Europe, expectations towards the state are high (naïve attitudes ask the state to be active in the equalization of chances, but prices of state services are underestimated), corruption and infringement of norms on a daily basis are generally accepted, and instrumentalization of norms is progressing. See Tóth, I.Gy., Bizalomhiány, normazavarok, igazságtalanságérzet és paternalizmus a magyar társadalom értékszerkezetében. A gazdasági felemelkedés társadalmi-kuturális feltételei címü kutatás zárójelentése, in: Tárki (ed.), A gazdasági felemelkedés társadalmi-kuturális feltételei címü kutatás zárójelentése, Budapest 2009; for recurring survey results on the grounds of WVS S5 see T. Keller, Értékek 2013. Október, in: Tárki (ed.), Bizalomhiány, normakövetés, az állam szerepéröl és a demokráciáról alkotott vélemények alakulása Magyarországon, Budapest 2013, www.tarki.hu/hu/research/gazdkult/index.html (accessed 20.09.2020). 
watchdog NGOs) have to be greatly developed in the future. Until that point of time, legal clinics will continue searching for their own sustainable and re-operating model in Hungary.

As it has been described above, free legal aid for people in need is available in a limited way and access to it is not straightforward for the growing circles of persons who are suffering from distress, hardship, and discrimination in Hungary. The state-financed legal assistance is partly accessible for city residents, while alternative, non-governmental legal aid should become stronger, including law practitioners' pro bono work. The work of students and tutors may also be considered as pro bono activity, since they provide legal advice for free and upon voluntary participation. ${ }^{27}$ If law practitioners and law students are not sensitive enough to the position of vulnerable and frustrated persons, social exclusion will also mean legal exclusion. Legal clinics in legal education may prevent this elimination and certainly could contribute to the development of the ethos of legal protectors in Hungary.

\section{References}

Badó A. et al., Összehasonlító motivációs vizsgálat a szegedi joghallgatók körében, "MTA Law Working Papers" 2017, No. 11.

Farkas É., Financing the adult education system in Hungary, in: B. Németh (ed.), Research and Development in Adult Learning and Education in Hungary, Bonn 2015.

Farkas É., The practice of adult education and vocational training in Hungary, Szeged 2013.

Feith H., Badó A., Magyar joghallgatók motivációs vizsgálata, "Jogelméleti Szemle" 2000, No. 4.

Kálmán R., Lengyel-magyar két jó barát, avagy a jogklinika programok összehasonlitó elemzése, in: Zs. Fejes (ed.), Jog és Kultúra, Szeged, 2018.

Keller T., Értékek 2013. október, in: Tárki (ed.), Bizalomhiány, normakövetés, az állam szerepéröl és a demokráciáról alkotott vélemények alakulása Magyarországon, Budapest 2013.

Körtvélyesi Zs., A magyar jogászképzés 2015-ben - A jogi karok helyzete, in: A. Jakab, G. Gajduschek (eds.), A magyar jogrendszer állapota, Budapest 2016.

Nagy Zs., A jogi oktatás fejlődése és aktuális kérdései, Szeged 2007.

Németné Doktor A., A magyarországi magán-felsőoktatás, “Új Pedagógiai Szemle" 2008, No. 8-9.

27 R. Kálmán, Lengyel-magyar két jó barát, avagy a jogklinika programok összehasonlító elemzése, in: Z. Fejes (ed.), Jog és Kultúra, Szeged 2018, p. 51. 
Tilak J.B.C., La privatisation de l'enseignement supérieur, "Perspectives” 1991, No. 2.

Tóth F., A jogklinikai képzés módszertana, in: ELTE, Oktatásmódszertani Füzetek, Vol. 4, Budapest 2017.

Tóth I.Gy., Bizalomhiány, normazavarok, igazságtalanságérzet és paternalizmus a magyar társadalom értékszerkezetében, in: Tárki (ed.), A gazdasági felemelkedés társadalmi-kulturális feltételei címü kutatás zárójelentése, Budapest 2009.

Tóth J., Legal Clinic as a Promising Alternative Instrument in Hungary, "Jogelméleti Szemle" 2017, No. 4.

Tóth J., Kézikönyv a jogklinikai képzéshez, Szeged 2017.

Visnyei V., A jogászképzés és a jogászi professziók Magyarországon, “Comparative Law Working Papers” 2018, No. 1, Special Issue by Students, pp. 60-64.

\section{CITATION}

Tóth J., Kálmán R., Legal education at the crossroads of social responsibility and the development of individual competencies - experience at the University of Szeged (Hungary), "Acta Iuris Stetinensis" 2021, No. 2 (Vol. 34), 59-74, DOI: 10.18276/ais.2021.34-04. 